DOI https://doi.org/10.30525/978-9934-26-073-5-2-77

\title{
FORMATION OF EMOTIONAL INTELLIGENCE IN LEARNING ENGLISH BY FUTURE SPECIALISTS: IMPORTANCE, RELEVANCE
}

\author{
Chava H. F. \\ English teacher \\ Nikopol College of Dnipro State Agrarian and Economic University \\ Nikopol, Dnipropetrovsk region. Ukraine
}

For a very long time there was an opinion that emotions are the cause of rash actions and prevent correct decision-making, reduce the efficiency of work. However, numerous studies have shown that emotions do not negatively affect the effectiveness of human activity. Moreover, they are our «satellites» and «advisers» which help in making the optimal decision, and also have a direct impact on the effectiveness of achieving educational and other goals.

Education unquestionably performs an important social function and is directly related to the introduction of leading technologies, developments, tools that can increase personal effectiveness to achieve professional development. The modern stage of the development of society poses high demands on specialists regarding the level of formation of their professional qualities. Emotional orientation and emotional intelligence have a mediated effect on the success of professional activity.

The modern paradigm of education considers the process of learning foreign languages as a process of foreign-language education, which includes the socio-cultural development of the individual and the formation of communicative competence. Knowledge of communicative skills is the basis of effective foreign language communication. They include the ability to express one's own thoughts, proficiency in dialogical and monological broadcasting, etc. However, in addition to this, it is important to be able to control and control the behavior of the interlocutor and solve conflict situations. These aspects are central to the teaching of foreign languages.

The ability to communicate effectively is the basis of educational standards. Numerous studies have shown that in order to achieve success and career growth, in addition to a high level of intelligence, it is important to be able to competently build the communication process and control the interlocutor's own emotions and emotions. Thus, increasingly teachers began to turn to the term «emotional intelligence» and the methods and methods of its formation. The concept of emotional intelligence includes «the ability of a 
person to recognize emotions, understand the intentions, motivation and desires of other people and his own, as well as manage his own emotions and emotions of other people in order to solve practical problems» [1].

According to the definition of S. J. Stein and Howard Beech, «emotional intelligence,» unlike the usual concept of «intelligence» for everyone, is the ability to correctly interpret and influence certain situations, intuitively feel what other people want and need, know their strengths and weaknesses, do not succumb to stress» [2].

The formation of emotional intelligence is facilitated by certain strategies of teachers:

- openness to the new, that is, constant expansion of the role space for each participant in the educational process;

- the right to choose, to stimulate cognitive interest, a sense of responsibility, the formation of internal freedom;

- emotional stability and stress resistance, providing the ability to carry out emotional exchange during communication, empathy, the ability to help others and themselves in difficult emotionally tense situations;

- the formation of adequate self-esteem and positive thinking, which affects the academic performance, because students who are convinced of their own strength, absorb new material much faster and more effectively;

- reflectivity and inclusion in the process of introspection, creating favorable conditions for the self-actualization of the person. [3, p. 260-264.]

It is known that many social, psychological and physiological deviations are associated precisely with the excessive load of the human nervous system and psyche, which occurs due to the inability to adapt to living conditions. It should be noted that when learning a foreign language, it is necessary to pay attention not only to the abilities of participants in the educational process and their intelligence, but also to the emotional sphere and psychological atmosphere, to direct their work to create a positive microclimate during training and to form a positive motivation for learning foreign languages.

In order for the training session to contribute to the maximum development of emotional intelligence, it is necessary to combine various methods and techniques:

- exercises to relieve psychological stress, anxiety, with elements of art therapy;

- tasks to increase self-evaluation;

- discussions;

- role-playing games;

- games aimed at verbal or non-verbal expression of one's own emotional state; 
- problematic situations;

- the task for the development of verbal and non-verbal means of communication;

- exercises and tasks on the association.

In the work on the formation of emotional intelligence of students an important role is played by such factors as:

- self-assessment;

- self-awareness;

- emotion management;

- motivation;

- empathy;

- social skills. [4]

It will not be superfluous to note the weight of the teacher's ability to properly organize activities and demonstrate his own example in designing success situations when achieving the goal in the work. The teacher must be educated in the topic and ready to work on new challenges, which the audience can establish.

Taking this into account, it will be advisable to introduce more roleplaying and situational games and exercises. In addition to working in small/medium-sized groups, applicants should cooperate with the teacher and invited outsiders (English-speaking teachers/psychologists), which will increase the level of spontaneity of the situation and help to find solutions to establish a favorable emotional climate in a completely new and not adapted team.

As a result, one can expect not only an increase in the self-awareness of individuals, but also a qualitative improvement of professional training and a completely new integrated approach to foreign language, professional and business interpersonal communication.

So, emotional intelligence is an indispensable factor that activates and elevates our mental dexterity; that is, when a person acknowledges his feelings and is guided by them in a constructive way, it increases the intellectual strength of the individual. It is quite possible to increase the level of your emotional intelligence, but not with the help of traditional training programs aimed at the part of the brain that controls our rational ideas. [5, p. 85-89.]

The formation of emotional intelligence is manifested in the teacher's ability to establish emotional contact with the team and with each participant in particular, to create an atmosphere of mutual understanding and trust in the classroom, to manage the feelings and thoughts of participants in the learning process. This phenomenon contributes to the ability of teachers to research and design their own activities, think and act in the professional field regardless of 
other people's will, circumstances, make choices and make appropriate decisions in difficult situations, develop behavioral strategies and achieve goals without excessive willpower.

Such qualities on the visual-reflective principle find echoes in students who are in the same educational space with the demonstrated role model and stimulate a more active process in both intellectual and emotional development. Accordingly, personal qualities are joined by professional ones, as the subject matter of the material in educational programs correlates as much as possible with professional activity and the baggage of knowledge and skills that will become the basis of professional activity.

The teacher must realize the importance of creating emotional comfort in the learning process, striving to provide it in practice, to have a sufficient level of self-development technologies that would provide not only recognition and self-control of their emotions, but also understanding of students' emotional states and ability to motivate their learning. for them the sphere of feelings and experiences.

The study of emotional features and the development of emotional intelligence is a task of paramount importance. It is relevant in solving problems of increasing the level of learning success, perception and understanding of another person as a person. Emotional literacy allows you to better understand the emotional functioning of people, to succeed in communication, to resolve conflicts, to understand yourself, your needs and desires, to set goals to achieve them. All this affects the effectiveness of knowledge acquisition.

Therefore, the teacher, in preparation for English classes with future professionals, should consider methods and techniques that will cause emotional uplift. Thus, the effectiveness of the development of emotional intelligence of students depends on the creation of psychological conditions in the educational institution and teachers' awareness of the importance of this area in professional activities.

\section{References:}

1. Goleman D. Emotional intelligence. - M.: AST, 2008. 236 s.

2. Stein S.J., Buk G.I. Advantages of EQ. Emotional intelligence and your successes. M .: Balance Business Books, 2007. $191 \mathrm{p}$.

3. Gondareva GV (2013). The concept of development of emotional intelligence of high school students in the educational process. Tavriya Bulletin of Education, (2), P. 260-264.

4. Shapiro L. How to raise a child with a high rate of emotional development. - M .: Eksmo, 2005. 
5. Kostyuk AV (2014). Emotional intelligence and ways of its development. Scientific Bulletin of Kherson State University, (2), P. 85-89.

DOI https://doi.org/10.30525/978-9934-26-073-5-2-78

\title{
МАТЕРІАЛИ ТЕD ТАLКS ЯК ДОДАТКОВИЙ ЗАСІБ НАВЧАННЯ ІНОЗЕМНОЇ МОВИ В СТАРШИХ КЛАСАХ ЗАКЛАДІВ ОСВІТИ
}

\author{
Шпак Т. С. \\ учитель англійської мови \\ Харківського лічуею № 141 \\ м. Харків, Украӥна
}

На теперішньому етапі свого розвитку українське суспільство зіткнулося 3 рядом важливих та нагальних викликів у різних сферах життя, які потребують якісного вирішення - це і активні євроінтеграційні процеси, інформатизація населення, і життя в умовах пандемії, тощо. А сучасний освітній простір один із тих, який потребує реформування та швидкого реагування на нагальні проблеми в таких непростих умовах. Слід також зауважити, що відповідно до засад розвитку освіти в України у XXI столітті іншомовна освіта знаходиться в центрі уваги реформаційних процесів освітньої сфери та $є$ одним із важливих складників сучасного освітнього процесу в закладах освіти. Сучасна мовна політика та проблеми в галузі вивчення та навчання іноземної мови як одного із засобів міжкультурного спілкування вимагають сучасних та інноваційних підходів до методики викладання, якісного удосконалення професійної та іншомовної комунікативної компетенції сучасних учителів, імплементації в навчальний процес сучасних засобів та технологій навчання.

Одним із таких засобів $є$ використання інформаційних та мультимедійних технологій у роботі з учнями на уроках іноземної мови, які відкривають нові можливості впровадження в освітній процес нових методів і прийомів навчання. Послуговуючись Концепцією нової української школи (2016) зазначимо, що використання інформаційних та мультимедійних технологій в освітній галузі має перейти від періодичного застосування в системний характер. Такі технології значною мірою розширюють спектр можливостей освітянина, оптимізують навчальні процеси, формуючи необхідні для сьогодення компетенції [1]. Парадигма інформаційних та мультимедійних засобів 